\title{
The Eskimo-Aleut Dentition: Crown and Root Morphology
}

\section{Denticija Eskima Aleuta: morfologija krune i korijena}

Department of Anthropology, University of Nevada Reno

Zavod za antropologiju Sveučilišta u Nevadi, Reno, SAD

\section{Abstract}

Objective of work: This paper provides an overview of crown and root morphology in Eskimo-Aleut populations of the American Arctic. For context, Eskimo-Aleut dental variation is compared to closely related American Indians and distantly related Europeans. Materials and methods: The characterization of dental trait frequency variation is based on observations made on approximately 10,000 dentitions scored by the late Christy G. Turner II and the author. Sixteen crown and five root traits were scored following the conventions outlined in the Arizona State University Dental Anthropology System. Results: Of the 21 dental traits considered, only three showed slight differences among Eskimo-Aleuts, American Indians, and Europeans (UM1 cusp 5, LM2 groove pattern, LM2 root number). For the remaining traits, there was typically a dramatic contrast between the two New World populations and Europeans. While generally similar, Eskimo-Aleuts and American Indians showed differences in UI1 winging, shoveling, and double shoveling, UM1 Carabelli trait, 2-cusped UM2, 3-rooted UM2, and especially 3-rooted LM1. Conclusion: The differences between the three groups are likely a product of genetic drift and founder effect although recent work on the EDAR V370A allele suggests some dental variables like shoveling and lower molar cusp number may indirectly reflect natural selection operating on other variables influenced by this allele.
Received: March 30, 2020

Accepted: May 25, 2020

Address for correspondence

G. Richard Scott

University of Nevada Reno

Department of Anthropology

Reno NV 89557

+1 775 750-3091

grscott@unr.edu

Key words

Tooth Crown; Tooth Root; Alaska Natives; North American Indians; European Continental Ancestry Group

\section{Introduction}

Linguistically, Eskimos and Aleuts are in the same language family (Eskaleutian), but they diverged from one another between four and five thousand years ago. Later, Eskimos diverged into two linguistic subgroups, Yupik and Inuit. Yupik speaking Eskimos are found on St. Lawrence, Nunivak, and Kodiak Islands, in the Yukon-Kuskokwim delta region of southwest Alaska, and a small area in far eastern Chukotka. Inuit speaking groups extend from the Seward Peninsula in western Alaska across the farthest reaches of northern Canada to east Greenland. Aleuts inhabit the Aleutian archipelago extending far into the Pacific from the southwest corner of Alaska (Fig 1).

In circumpolar North America, Aleuts and Eskimos range from $174.2^{\circ} \mathrm{W}$ (western Aleuts) to $10^{\circ} \mathrm{W}$ longitude (East Greenland Eskimos). Living primarily on islands or along coastlines, subsistence adaptations are predominantly maritime. Depending on location, groups subsist on whales, walrus, diverse seal species, and anadromous fish (e.g., salmon, Arctic char). Terrestrial resources like caribou and musk oxen are utilized by groups who can exploit both inland and coastal resources. In many areas, winters are long and cold while summers are short and cool. During most of the year, the diet is high in protein and fat and deficient in carbohydrates and calcium. During the winter, the primary staple is the dried flesh of marine mammals and fish (1).

\section{Uvod}

Eskimi i Aleuti jezično pripadaju istoj zajednici (Eskaleuti), ali razišli su se prije četiri ili pet tisuća godina. Poslije su se Eskimi razdvojili u dvije jezične podskupine - jupik i inuit. Eskimi koji govore jupikom žive na otocima Sveti Lawrence, Nunivak i Kodiak, u delti Yukon-Kuskokwima na jugozapadu Aljaske i na malom području na krajnjem istoku Čukotskog poluotoka. Skupine koje se služe inuitskim jezikom rasprostranjene su od poluotoka Sewarda na zapadnoj Aljasci preko najudaljenijih dijelova sjeverne Kanade do istočnoga Grenlanda. Aleuti nastanjuju Aleutski arhipelag koji se proteže daleko u Tihi ocean od jugozapadnoga kuta Aljaske (slika 1.).

U cirkumpolarnoj Sjevernoj Americi Aleuti i Eskimi zauzimaju prostor od $174,2^{\circ} \mathrm{Z}$ (zapadni Aleuti) do $10^{\circ} \mathrm{Z}$ geografske dužine (istočni grenlandski Eskimi). Žive uglavnom na otocima ili duž obale i prilagodili su se životu uz more i na moru. Ovisno o lokaciji, skupine obitavaju s kitovima, morževima, raznim vrstama tuljana i anadromnim ribama (npr., losos i druge arktičke ribe). Kopnene životinje poput sobova i mošusnih goveda dostupne su skupinama koje mogu iskorištavati kopnene i obalne resurse. U mnogim su područjima zime duge i hladne, a ljeta kratka i prohladna. Tijekom većine godine prehrana je bogata proteinima i masnoćama, a nedostaje ugljikohidrata i kalcija. Zimi je osnovna namirnica sušeno meso morskih sisavaca i riba (1). 
Although many people envision Eskimos living in igloos (ice houses) in a snow-covered landscape, this describes mostly groups living in central Canada. Environments inhabited by circumpolar populations are quite diverse. The Aleutian archipelago is comprised of 69 volcanic islands that extend across $1900 \mathrm{~km}$. Temperatures are moderated by a cool wet maritime environment so Aleuts, like Scandinavians, have more issues with hypothermia than frostbite. Kodiak Island, the Alaska Peninsula, and southwest Alaska likewise provide relatively benign environmental settings where adjacent seas never freeze. These temperate environments are inhabited by Aleuts and Yupik Eskimos.

The lower latitude groups provide a stark contrast to their northerly neighbors who contend with frozen seas annually. The northern groups who experience severe cold and dry winters are the Inuit. These populations had to adapt their clothing and shelter to avoid frostbite and allow movement across the landscape for subsistence activities. To combat subzero temperatures and high winds and lacking any other material, central Canadian Inuit built igloos out of ice blocks. In northern Alaska and much of Greenland, some combination of turf, stone, driftwood, whale bones, and animal hides were used to construct semi-subterranean shelters with depressed Arctic entryways that limited heat loss from the primary living area (2).

Eskimo-Aleuts are not recent arrivals to the New World as once thought. During the latter stages of the Upper Pleistocene (date range: 128,000 to $12,000 \mathrm{BP}$ ), populations in northeast Siberia and western Alaska were gradually shifting their range eastward toward the Americas when movement was thwarted by coastal glaciers and massive ice sheets that covered most of Canada. The ancestors of Eskimo-Aleuts were one element of a large population system that was distributed across greater Beringia from roughly 30,000 to 15,000 years before present. This so-called Beringian Standstill population included the ancestors of both American Indians and Eskimo-Aleuts (3). Around 15,000 years ago, the ancestors of American Indians broke out of the standstill and made their way down the coast into the Pacific Northwest. Once they reached this glacier-free landscape, they dispersed across the Americas from the Pacific to the Atlantic and from the northwest coast of North America to Tierra del Fuego, the southernmost point of South America.

While the ancestral-descendent groups of American Indians ultimately inhabited most of North America and the entirety of South America, Eskimo-Aleuts carved out their place in the Americas by settling the coasts and islands of subarctic and Arctic North America (4). Although their ancestors were part of the larger Native American standstill population during the late Pleistocene, their geographic placement remains in proximity to Northeast Asian populations. Through some combination of gene flow and adaptations to similar environmental settings, Eskimo-Aleuts show more ties to Northeast Asians than do American Indians. For example, Northeast Asians have a high frequency of blood group allele B (20-30\%), a gene that is lacking in American Indians. Eskimo-Aleuts have the allele B but in much lower frequency than in Northeast Asians (ca. 5\%). Another Asian trait, the
Iako mnogi smatraju da Eskimi žive u igluima (ledenim kućama) u krajoliku prekrivenom snijegom, to uglavnom vrijedi za one u središnjoj Kanadi. Okružja u kojima boravi cirkumpolarna populacija dosta su raznolika. Tako se Aleutsko otočje sastoji se od 69 vulkanskih otoka rasprostranjenih na području od $1900 \mathrm{~km}$. Na temperaturu utječe hladno, vlažno morsko okružje, tako da Aleuti, poput Skandinavaca, imaju više poteškoća $s$ hipotermijom negoli sa smrzavanjem. Otok Kodiak, poluotok Aljaske i jugozapadna Aljaska također imaju razmjerno blage vanjske uvjete - tamošnja se okolna mora nikada ne zamrznu. Te umjerene sredine naseljavaju Aleuti i Eskimi Jupici.

Skupine u nižim širinama izrazit su kontrast svojim sjevernim susjedima koji se godišnje bore sa zamrznutim morima. Sjeverne skupine koje žive u područjima s jakim, hladnim i suhim zimama su Inuiti. Te su populacije morale prilagoditi svoju odjeću i skloništa kako bi izbjegle promrzline i omogućile kretanje radi životnih aktivnosti. U borbi protiv niskih temperatura i snažnih vjetrova, a u nedostatku bilo kojega drugog materijala, ti kanadski Inuiti počeli su graditi kućice od ledenih blokova. U sjevernoj Aljasci i većem dijelu Grenlanda kombinacija trave, kamena, kosti kitova i životinjske kože korištena je za izradu polupodzemnih skloništa s arktičkim ulazima koji su ograničavali gubitak topline iz primarnoga životnog područja (2).

Eskimi Aleuti nisu tek nedavno došli u Novi svijet kao što se nekoć mislilo. Tijekom posljednje faze gornjeg pleistocena (datumski raspon: 128000 do 12000 pr. Kr.), stanovništvo u sjeveroistočnom Sibiru i zapadnoj Aljasci postupno se pomicalo istočno prema Americi, pri čemu su kretanje ometali obalni ledenjaci i masivni ledeni slojevi koji su prekrivali veći dio Kanade. Predci Eskima Aleuta bili su jedan element velikoga populacijskog sustava raspoređenog po većem dijelu Beringije prije otprilike 30000 do 15000 godina. To stanovništvo obuhvaćalo je i pretke američkih Indijanaca i Eskima Aleuta (3). Prije otprilike 15000 godina predci američkih Indijanaca krenuli su niz obalu na sjeverozapad Pacifika. Kad su stigli do krajolika bez ledenjaka, raspršili su se diljem obiju Amerika - od Tihog oceana do Atlantika i od sjeverozapadne obale Sjeverne Amerike do Ognjene Zemlje, najjužnije točke Južne Amerike.

Dok su skupine potomaka američkih Indijanaca na kraju naselile veći dio Sjeverne Amerike i cijelu Južnu Ameriku, Eskimi Aleuti odredili su svoje mjesto u Americi naseljavajući obale i otoke subarktičke i arktičke Sjeverne Amerike (4). Iako su njihovi predci činili dio veće populacije Indijanca u gornjem pleistocenu, njihov zemljopisni položaj ostao je u blizini populacije sjeveroistočne Azije. Kombinacijom protoka gena i prilagodbe sličnim okolišnim uvjetima, Eskimi Aleuti pokazali su snažnije veze s Azijcima sa sjeveroistoka negoli s Amerikancima. Na primjer, sjeveroistočni Azijci imaju veliku učestalost alela krvne grupe B $(20-30 \%)$, gena koji nedostaje američkim Indijancima. Eskimi Aleuti imaju alel B, ali mnogo rjeđe negoli sjeveroistočni Azijci (oko 5\%). Drugo azijsko svojstvo - epikantični pregib očiju češći je kod Eskima Aleuta negoli američkih Indijanaca. Mnoga druga genetska i morfološka svojstva imaju isti obrazac, uključujući i neka dentalna obilježja koja su uočena poslije. 
epicanthic eye-fold, is more common in Eskimo-Aleuts than in American Indians. Many other genetic and morphological traits exhibit the same pattern, including some dental traits that are noted later.

Physically, Eskimos are often used as a textbook illustration of ecogeographical rules. They have relatively short limbs relative to trunk length (high sitting height ratio), illustrative of Bergmann's Rule. Limb length is also reduced in conformance with Allen's Rule. In other words, they have a physique that maintains body heat in an environment where ambient temperatures are often well below zero degrees (5, 6). Eskimo-Aleuts also have some of the world's largest cranial capacities, a characteristic also interpreted in terms of climatic adaptation. Regarding the distribution of cranial capacity relative to stature, the highest values mirror almost exactly the distribution of Eskimo-Aleut populations in the New World (7).

Waugh $(8,9)$ measured bite force between the upper and lower first molars of Eskimo males and females and arrived at average values of 280 psi for males and 240 psi for females. Europeans, by contrast, generate bite forces between 90 and 120 psi. In 1977, W.L. Hylander (10) wrote an article entitled "The adaptive significance of Eskimo craniofacial morphology." He detailed many unique characteristics that are associated with the production and dissipation of pronounced vertical occlusal forces. Changes involved in generating large bite forces include reduced prognathism where the face is situated more directly under the frontal bone. Hypertrophied temporal muscles are reflected in high and pronounced temporal lines on the parietals along with distinct sagittal keeling. Large masseter muscles are indicated by distinct gonial eversion and broad ascending rami. Characters that reflect the dissipation of forces include pinched nasal bones and thickened tympanic plates. Perhaps tied to this in some way, Eskimo-Aleuts have the world's highest frequencies of palatine and mandibular tori $(11,12)$.

Directly affecting teeth, pronounced bite force can stress dental enamel beyond its breaking point. Although individuals in all populations chip their teeth, the extent of dental chipping in Eskimos is unparalleled. Turner and Cadien (13) noted that dental chipping was far more common in Eskimos than in Aleuts, reflecting a difference in jaw mechanics and dietary behavior. Far more than Aleuts, Eskimos consumed tough, frozen foods that included grit added by accident during the drying process. Scott and Winn (14) note that when Europeans show dental chipping, it is largely confined to the anterior teeth. St. Lawrence Island Eskimos, by contrast, show high levels of chipping on both the anterior and posterior teeth.

Early Arctic explorers noted how the Eskimo used their teeth as tools, like a third hand. The anterior teeth were often used by females to soften frozen boots. Males used their anterior teeth for a variety of tasks, producing a rounded form of wear on the incisors. One by-product of this wear was shortening the roots of the upper incisors $(10,20)$. I have observed dentitions of middle-aged Eskimos where the length of the root was shorter than the height of the crown. This often led to premature tooth loss, sometimes interpreted as intention-
Fizički se Eskimi često u udžbenicima koriste kao ilustracija za ekogeografska pravila. Imaju razmjerno kratke udove u odnosu prema dužini trupa (visok omjer sjedenja), što ilustrira Bergmannovo pravilo. Dužina udova smanjuje se u skladu s Alenovim pravilom. Drugim riječima, imaju tijelo koje održava toplinu u okružju u kojemu su temperature okoliša često znatno ispod nula stupnjeva $(5,6)$. Eskimi Aleuti ubrajaju se među ljude s najvećim kranijalnim kapacitetom, što se također tumači kao klimatska prilagodba. Kad je riječ o raspodjeli kranijalnog kapaciteta u odnosu prema tijelu, najveće vrijednosti odražavaju gotovo točno raspodjelu populacije Eskima Aleuta u Novom svijetu (7).

Waugh $(8,9)$ je izmjerio žvačnu silu između prvoga gornjeg i donjeg kutnjaka Eskima i zabilježio je prosječne vrijednosti od 280 psi za muškarce i 240 psi za žene. Suprotno tomu, Europljani razvijaju žvačnu silu između 90 i 120 psi. Godine 1977. W. L. Hylander (10) je napisao članak pod naslovom Značenje prilagodljive eskimske kraniofacijalne morfologije. Detaljno je opisao mnoga jedinstvena obilježja koja su povezana sa stvaranjem i rasipanjem izraženih vertikalnih okluzijskih sila. Promjene koje su uključene u stvaranje velikih žvačnih sila obuhvaćaju smanjeni prognatizam, gdje se lice nalazi direktnije ispod čeone kosti. Temporalni mišići su hipertrofični. Veliki maseteri upućuju na izrazitu gonijalnu everziju i širok uzlazni ramus. Obilježja koja odražavaju rasipanje sila uključuju izbočene nosne kosti i zadebljane timpanične ploče. Možda na neki način vezano za ovo, Eskimi Aleuti imaju najveću učestalost palatinalnog i mandibularnog torusa na svijetu $(11,12)$.

Velika žvačna sila koja djeluje izravno na zub može opteretiti caklinu tako da dosegne točku lomljenja. Iako se frakture cakline događaju pojedincima u cijeloj populaciji, kod Eskima je to posebno izražena pojava. Turner i Cadien (13) primijetili su da su frakture cakline mnogo češće kod Eskima negoli kod Aleuta, odražavajući razliku u mehanici čeljusti i prehrambenom ponašanju. Znatno češće od Aleuta, Eskimi su konzumirali žilavu, smrznutu hranu. Scott i Winn (14) istaknuli su da, kada Europljanima pukne caklina, to je uglavnom ograničeno na prednje zube. Eskimima s otoka St. Lawrencea često puca caklina na prednjim i stražnjim zubima.

Rani istraživači Arktika uočili su da Eskimi upotrebljavaju svoje zube kao oruđe, kao treću ruku. Prednjim zubima žene su se često koristile pri omekšavanju smrznutih čizama. Muškarci su upotrebljavali prednje zube za razne zadatke, što je uzrokovalo zaobljeno trošenje na sjekutićima. Jedna od nuspojava toga trošenja bilo je skraćivanje korijena gornjih sjekutića $(10,20)$. Zapaženo je da je u denticiji sredovječnih Eskima dužina korijena bila kraća od visine krune. To je često bio razlog za preuranjeni gubitak zuba, što se katkad tumačilo kao namjerno ili ritualno vađenje (14). S obzirom na vrijednost prednjih zuba u životu Eskima, namjerno uklanjanje bilo bi kontraproduktivno (15), pa bi prerani gubitak prednjih zuba vjerojatno mogao biti povezan $s$ upotrebom zuba kao alata.

Neki su istraživači nagađali o ulozi morfologije krune i korijena kao o mogućoj prilagodbi okolišu i prehrambenom ponašanju Eskima Aleuta. Na primjer, sjekutići u obliku lo- 
al tooth removal, or ritual ablation (14). Given the value of the anterior teeth in Eskimo life, intentional removal would have been behaviorally counter-productive (15), so premature loss of anterior teeth was likely tied to tooth-tool use and shortened roots.

Some researchers have speculated on the role of crown and root morphology as possible adaptations to the environment and dietary behavior of Eskimo-Aleuts. For example, shovel-shaped incisors provide added crown area that could strengthen and prolong the useful life of the anterior teeth. Three-rooted lower first molars, which find their highest frequencies in Eskimo-Aleuts, provide an anchor to the lower first molar that could prolong the functional life of that important tooth. To determine if there is any veracity to these suggestions, I turn to the substance of this paper - EskimoAleut crown and root morphology.

\section{Eskimo-Aleuts and dental anthropology}

A key dividing line in the field of dental anthropology is the 1963 volume edited by D.R. Brothwell (16) entitled Dental Anthropology (17). Prior to that date, four monographs focused on the dentitions of specific geographic populations: T.D. Campbell on Australian aboriginals (18), J.C. Middleton-Shaw on Bantus (19), P.O. Pedersen on East Greenland Eskimos (20), and C.F.A. Moorrees on Aleuts (21). Early research on Eskimo-Aleuts played a significant role in the development of dental anthropology. Another pioneer in the field, Albert A. Dahlberg, is best remembered for his work on Southwest Indians and American whites, but he was the dental researcher brought in to work on Alaskan populations as part of the Human Adaptability Project, a subdivision of the International Biological Program (1964-1974). In this context, Dahlberg collected dental casts of living populations from Kodiak Island and Wainright, Alaska (22) and later studied St. Lawrence Island Eskimo dentitions.

Influenced by the research of B.S. Kraus (23) on the genetics of dental morphological trait expression and the standard plaques for scoring tooth crown traits developed by A.A. Dahlberg (24), C.G. Turner II initiated research on tooth crown and root variation in Eskimos and Aleuts in the early 1960s. This work culminated in a doctoral dissertation entitled The Dentition of Arctic Peoples (25, 26). Turner ultimately went on to make observations on the dental morphology of ca. 24,000 skeletons from the Americas, Northeast and Southeast Asia, the Pacific, and Europe, but he never abandoned his first focus, Eskimos and Aleuts. The combined Eskimo sample he observed numbered 1317 individuals from Alaska, Siberia, Canada, and Greenland. For eastern and western Aleuts, he scored 405 individuals. In addition to Turner's large database, I made observations on 759 Alaskan Eskimo dentitions during my tenure at the University of Alaska Fairbanks.

This summary article characterizes crown and root traits in Eskimo-Aleuts based on the combined samples of Turner and Scott totaling 2481 individuals. Frequencies without comparisons lack context so I include trait frequencies for a large combined sample of North and South American Indi- pate povećavaju površinu krune, a to može ojačati i produljiti vijek prednjih zuba. Trokorijenski prvi donji kutnjaci koji imaju najveću frekvenciju među Eskimima Aleutima, služe kao sidro donjem prvom kutnjaku, što može produljiti funkcionalni vijek toga važnog zuba. Da bi se utvrdilo jesu li te pretpostavke istinite, ovaj se rad bavi morfologijom krune i korijena Eskima Aleuta.

\section{Eskimi Aleuti i dentalna antropologija}

Ključna granica razdvajanja u području dentalne antropologije jest svezak iz 1963. koji je uredio D. R. Brothwell (16) pod nazivom Dentalna antropologija (17). Prije tog datuma autori četiriju monografija usredotočili su se na denticiju određenih geografskih populacija - T. D. Campbell je pisao o australskim starosjediocima (18), J. C. Middleton-Shaw o Bantusima (19), P. O. Pedersen o Eskimima s Istočnog Grenlanda (20) i C. F. A. Moorrees o Aleutima (21). Rana istraživanja o Eskimima Aleutima bila su vrlo važna u razvoju dentalne antropologije. Još jedan pionir na tom polju - Albert A. Dahlberg - uglavnom se pamti po svojem radu o jugozapadnim Indijancima i američkim bijelcima, iako je bio istraživač određen da radi na populaciji Aljaske u sklopu Projekta ljudske prilagodljivosti kao dijela Medunarodnoga biološkog programa (1964. - 1974.). U tom je kontekstu Dahlberg prikupio odljeve zuba živih populacija s otoka Kodiaka i Wainrighta na Aljasci (22), a poslije je proučavao i denticije Eskima s otoka St. Lawrencea.

Pod utjecajem istraživanja B. S. Krausa (23) o genetici ekspresije dentalnih morfoloških obilježja i standardnih ploča za ocjenjivanje svojstava zubne krune koje je razvio A. A. Dahlberg (24), C. G. Turner II. pokrenuo je početkom 1960-ih istraživanje o promjenama na kruni i korijenu zuba Eskima i Aleuta. To je djelo kulminiralo disertacijom pod nazivom Denticija arktickih ljudi (The Dentition of Arctic People) (25, 26). Turner je na kraju nastavio proučavati dentalnu morfologiju na oko 24000 kostura iz Amerike, sjeveroistočne i jugoistočne Azije, Tihog oceana i Europe, ali nikad se nije odrekao svojeg prvog fokusa - Eskima i Aleuta. Kombinirani uzorak Eskima koji je analizirao bio je sastavljen od 1317 ispitanika s Aljaske i Grenlanda te iz Sibira i Kanade. Istočne i zapadne Aleute zastupalo je 405 pojedinaca. Uz Turnerovu veliku bazu podataka i sām sam proučio 759 Eskima s Aljaske tijekom mog rada na Sveučilištu Alaska Fairbanks.

U ovom preglednom radu sažete su spoznaje o obilježjima krune i korijena zuba Eskima Aleuta na temelju kombiniranih uzoraka Turnera i Scotta, što ukupno čini 2481 ispitanika. Frekvencijama bez usporedbe nedostaje kontekst, tako da ubrajam i frekvencije obilježja za veliki kombinirani uzorak Indija- 
ans (>5000 individuals) who are like their neighbors in the Arctic but show interesting differences. Since the audience of this article is most familiar with European teeth, frequencies from a large combined eastern and western European sample ( $>2000$ individuals) provides a second point of reference. If the reader is interested in broader world comparisons involving African, Asian, and Pacific populations, these are available in Scott and Turner (27) and Scott et al. (28).

\section{Dental Morphology}

Turner et al. (29) describe 38 dental and three jaw traits as part of the Arizona State University Dental Anthropology System. That widely cited article only had four illustrations, but this limitation was rectified in recent volumes by Scott and Irish (30) and Edgar (31), which include hundreds of photos and line drawings of over three dozen crown, root, and jaw traits. Additional illustrations of the traits that make up ASUDAS can be found in Scott et al. $(28,32)$ and Scott and Dumančić (33).

In his many population studies that focused on Native American, Northeast and Southeast Asian, and Pacific populations, Turner developed a list of 29 key crown and root traits (no jaw traits are included in this list). After Turner's untimely passing in 2013 (34), I assumed the task of preserving his data for posterity in what I refer to as the Christy G. Turner II Legacy Project. This involved scanning 24,000 individual data sheets and hundreds of computer printouts that show the full class frequency distributions for his 29 key traits. To see how the data are organized, the appendix of Scott and Irish (30) is comprised of 60 tables for some of Turner's largest samples.

In this overview of the Eskimo dentition, I selected 16 crown traits and five root traits from the key trait list of Turner. Note that: $\mathrm{U}=$ upper or maxillary, $\mathrm{L}=$ lower or mandibular; $\mathrm{I}=$ incisor, $\mathrm{C}=$ canine, $\mathrm{P}=$ premolar, $\mathrm{M}=$ molar; 1 , 2 , or $3=$ number in tooth district. These are broken down into four groups: (1) anterior teeth; UI1 bilateral winging, UI1 shoveling, UI1 double shoveling, and UI2 interruption grooves; (2) maxillary traits: UM1 Carabelli trait, 3-cusped UM2, UM1 cusp 5, UM1 enamel extensions, and peggedreduced-missing UM3; (3) mandibular traits: LP2 lingual cusp number, UP and LP odontomes, 4-cusped LM2, LM2 Y groove pattern, LM1 cusp 6, LM1 cusp 7, and LM1 deflecting wrinkle; and (4) root traits; 2-rooted UP1, 3-rooted UM2, 2-rooted LC, 3-rooted LM1, and 2-rooted LM2. The break points for each trait are shown in histograms.

\section{Anterior traits}

When I refer to anterior traits, it is directed at the upper incisors and canines. Europeans have relatively simple anterior teeth, only broken up on occasion by cingular tubercles (tuberculum dentale). Asian and Asian-derived populations provide a significant contrast. They commonly exhibit one of the best-known morphological traits of the human dentition: shovel-shaped incisors (35). The hallmark of shoveling is pronounced lingual marginal ridges. A related trait on the labial naca iz Sjeverne i Južne Amerike (> 5000 pojedinaca) koji su poput svojih susjeda na Arktiku, ali sa zanimljivim razlikama. Budući da su čitatelji ovog članka najbolje upoznati sa zubima Europljana, frekvencije iz velikoga kombiniranog uzorka istočne i zapadne Europe (> 2000 pojedinaca) druga su referentna točka. Ako čitatelja zanima šira svjetska usporedba koja uključuje afričku, azijsku i pacifičku populaciju, dostupna je u radovima Scotta i Turnera (27) te Scotta i suradnika (28).

\section{Dentalna morfologija}

Turner i suradnici (29) opisuju 38 obilježja zuba i tri obilježja čeljusti kao dio Dentoantropološkog sustava Državnoga sveučilišta u Arizoni. Taj često citirani rad sadržavao je samo četiri ilustracije, ali to je ograničenje ispravljeno u nedavno objavljenim svescima Scotta i Irisha (30) i Edgara (31) koji uključuju stotine fotografija i crteža kruna, korijena i čeljusti. Dodatne ilustracije obilježja koja čine ASUDAS mogu se naći u radovima Scotta i suradnika $(28,32)$ te Scotta i Dumančić (33).

U svojim mnogobrojnim populacijskim studijama koje su se usredotočile na populacije Indijanca, sjeveroistočne i jugoistočne Azijce i pacifičke populacije, Turner je sastavio popis od 29 ključnih obilježja krune i korijena (u taj popis nisu uvrštena obilježja čeljusti). Nakon što je Turner prerano umro 2013. (34), preuzeo sam zadatak da sačuvam njegove podatke za potomstvo u onome što nazivam naslijeđenim projektom Christyija G. Turnera II. To je uključivalo skeniranje 24000 pojedinačnih listova podataka i stotine računalnih ispisa koji pokazuju raspodjelu frekvencija za njegovih 29 ključnih obilježja. Da bi se vidjelo kako su podatci organizirani, prilog Scotta i Irisha (30) sastoji se od 60 tablica s nekim od Turnerovih najvećih uzoraka.

$\mathrm{U}$ ovom preglednom radu o denticiji Eskima odabrao sam 16 obilježja krune i pet obilježja korijena s Turnerovih popisa. Kratice su: $\mathrm{U}=$ gornji ili maksilarni, $\mathrm{L}=$ donji ili mandibularni; $\mathrm{I}=$ sjekutić, $\mathrm{C}=$ očnjak, $\mathrm{P}=$ pretkutnjak, $\mathrm{M}$ = kutnjak; 1, 2 ili 3 = broj zuba u skupini. Oni se dijele na četiri skupine: (1) prednji zubi; UI1 bilateralna meziopalatinalna rotacija (krilni V-postav), lopatasti oblik UI1, labijalno lopatasti oblik UI1 i interupcijeske brazde na UI2; (2) obilježja gornjih zuba: UM1 Carabellijevo svojstvo, 3 kvržice na UM2, kvržica 5 na UM1, ekstenzije cakline na UM1 i reducirani ili nedostajući UM3; (3) obilježja donjih zuba: broj lingvalnih kvržica na LP2, odontomi na UP i LP, Y fisurni crtež na LM2, kvržica 6 na LM1, kvržica 7 na LM1 i defleksijski nabor na LM1 i (4) obilježja korijena; dvokorijenski UP1, trokorijenski UM2, dvokorijenski LC, trokorijenski LM1 i dvokorijenski LM2. Prijelomne točke za svako svojstvo prikazane su u histogramima.

\section{Obilježja prednjih zuba}

Kad je riječ o obilježjima prednjih zuba, misli se na gornje sjekutiće i očnjake. Europljani imaju razmjerno jednostavnu morfologiju prednjih zuba koja je povremeno razbijena cingularnim tuberkulima (tuberculum dentale). Stanovništvo Azije i azijskoga podrijetla tu se znatno razlikuje. Obično imaju jedno od najpoznatijih morfoloških obilježja ljudskih zuba lopataste sjekutiće (35). Obilježje lopatastih sjekutića je naglašeni lingvalni rubni greben. Srodno obilježje na labijalnoj 
surface is referred to as double-shoveling. Another trait rare in Europeans but common in Asian populations is bilateral winging of the upper central incisors. The final trait, interruption grooves of the upper incisors, either crosscut marginal ridges or extend from the crown to the root, constituting corono-radicular grooves. These traits are illustrated in Fig. 2.

In Fig. 3, the major differences between Native Americans and Europeans in the anterior teeth are indicated. Europeans exhibit low frequencies of UI1 winging, shoveling, and double shoveling, a characterization that stands in marked contrast to the two Native American groups. American Indians have the world's highest frequencies of these three traits. In all three instances, the frequencies are significantly lower in Eskimo-Aleuts. Only for UI2 interruption grooves do Eskimo-Aleut frequencies exceed those of American Indians, with both being slightly higher than Europeans. Interruption grooves are the only trait where European frequencies approximate those of Native Americans.

\section{Maxillary crown traits}

Upper premolars exhibit morphological variation in terms of accessory ridges and tubercles, but these do no show clearly patterned variation among modern human groups. The most interesting variation is expressed on the upper molars. Three of the five traits are expressed on UM1: Carabelli trait (a cingular tubercle on the lingual surface of the mesiolingual cusp), cusp 5 (an accessory cuspule on the distal marginal ridge between the metacone and hypocone), and enamel extensions (cervical enamel line extends toward the interradicular projection between the two buccal roots of upper molars). Cusp number, dictated primarily by the presence and expression of the hypocone, is scored on UM2 because its expression is largely invariant on UM1. Finally, Turner combined UM3 congenital absence with size reduction, which is considered a single trait noted as pegged-reduced-missing UM3. These traits are shown in Fig. 4.

For the most part, Europeans have a relatively simplified dentition, referred to as the "Eurodont pattern" by Scott et al. (36). One trait that is more common and often quite pronounced in Europeans is the Carabelli trait. The histogram shows the frequency of all but the lowest grade of Carabelli expression (Fig. 5). Following this or any other breakpoint, European frequencies far exceed those of Native Americans. For the two groups of Native Americans, American Indians have a higher frequency than Eskimo-Aleuts. All Native Americans have a very low frequency of pronounced cusp or tubercle expressions (37), with Eskimo-Aleuts exhibiting the lowest frequencies in the world for all forms of Carabelli expression.

Living and fossil hominoids and early fossil hominins invariably exhibit four cusped upper molars. In modern humans, the cusps of the trigon (paracone $[\mathrm{MB}]$, metacone $[\mathrm{DB}]$, protocone $[\mathrm{ML}]$ ) are typically retained although the metacone is sometimes reduced in size. The key cusp is the hypocone [DL], the last major cusp of the upper molars added to the tribosphenic crown (i.e., trigon) of early primate maxillary molars (38). Following the general principle 'last cusp on, first cusp off,' the hypocone is often absent on površini jest dvostruko lopatasti tj. labijalno lopatasti oblik. Drugo obilježje rijetko kod Europljana, ali često u azijskoj populaciji, jest bilateralna meziopalatinalna rotacija (krilni Vpostav) gornjih središnjih sjekutića. Još jedno obilježje su interrupcijske brazde na gornjim sjekutićima koji ili presijecaju rubne grebene ili se protežu od krune do korijena tvoreći korono-radikularne žljebove. Ta su obilježja prikazana na slici 2.

$\mathrm{Na}$ slici 3. naznačene su glavne razlike između američkih domorodaca i Europljana kad je riječ o prednjim zubima. Europljani imaju nisku frekvenciju krilnog V-postava i lopatastih sjekutića UI1, što je u izrazitoj suprotnosti s dvjema skupinama američkih domorodaca. Američki Indijanci imaju najveću frekvenciju tih obilježja na svijetu. Frekvencije su značajno niže kod Eskima Aleuta. Samo za interrupcijske brazde na UI2, frekvencije kod Eskima Aleuta nadmašuju frekvencije američkih Indijanaca, s tim da su u oba slučaja malo više u usporedbi s Europljanima. Interrupcijske brazde jedino su obilježje kod kojega se frekvencija kod Europljana približava frekvenciji američkih domorodaca.

\section{Obilježja gornjih stražnjih zuba}

Gornji pretkutnjaci imaju morfološke varijacije u obliku fisura i kvržica, ali nisu jasno šablonske među suvremenim ljudskim skupinama. Najzanimljivija je ona na gornjim kutnjacima. Tri od pet obilježja izražena su na UM1: Carabellijevo svojstvo (cingularni tuberkul na palatinalnoj plohi meziolingvalne kvržice), peta kvržica (dodatna kvržica na distalnom rubnom grebenu između metakonusa i hipokonusa) i ekstenzije cakline (cervikalna granica cakline proteže se prema interradikularnoj brazdi između dvaju bukalnih korijena gornjih kutnjaka). Broj kvržica koji je diktiran ponajprije prisutnošću i ekspresijom hipokonusa, ocjenjuje se na UM2 jer je njegova ekspresija uglavnom invarijantna na UM1. Konačno, Turner je kombinirao prirođenu odsutnost UM3 sa smanjenjem veličine, što se smatra jednim obilježjem koje se manifestira kao reducirani ili nedostajući UM3. Ta su obilježja prikazana na slici 4.

U većini slučajeva Europljani imaju razmjerno pojednostavljenu denticiju koju Scott i suradnici nazivaju eurodontski obrazac (36). Jedno obilježje koje je češće i prilično izraženo kod Europljana jest Carabellijevo svojstvo. Histogram pokazuje frekvenciju svih obilježja, osim najmanjeg stupnja za Carabellijevo svojstvo (slika 5.). Frekvencija kod Europljana daleko nadmašuje onu kod američkih domorodaca. Između dviju skupina američkih domorodaca, američki Indijanci imaju veću frekvenciju od Eskima Aleuta. Svi američki domorodci imaju vrlo nisku frekvenciju dodatnih kvržica (37), a Eskimi Aleuti imaju najniže frekvencije na svijetu za sve oblike Carabellijeva svojstva.

Živi i fosilni hominoidi i rani fosilni hominini imaju četiri gornja kutnjaka. Kod suvremenih ljudi kvržice trigonida (parakonus [MB], metakonus [DB], protokonus [ML]) obično se zadržavaju, iako je metakonus katkad smanjen. Ključna kvržica je hipokonus (DL), posljednja velika kvržica na gornjim kutnjacima koja je dodana tribosfeničnoj kruni (tj. trigonu) (38). Slijedeći opće načelo zadnja kvržica dodana, prva oduzeta, hipokonusa često nema na drugom gornjem kutnjaku suvremenog čovjeka, što rezultira stvaranjem zuba s trima 

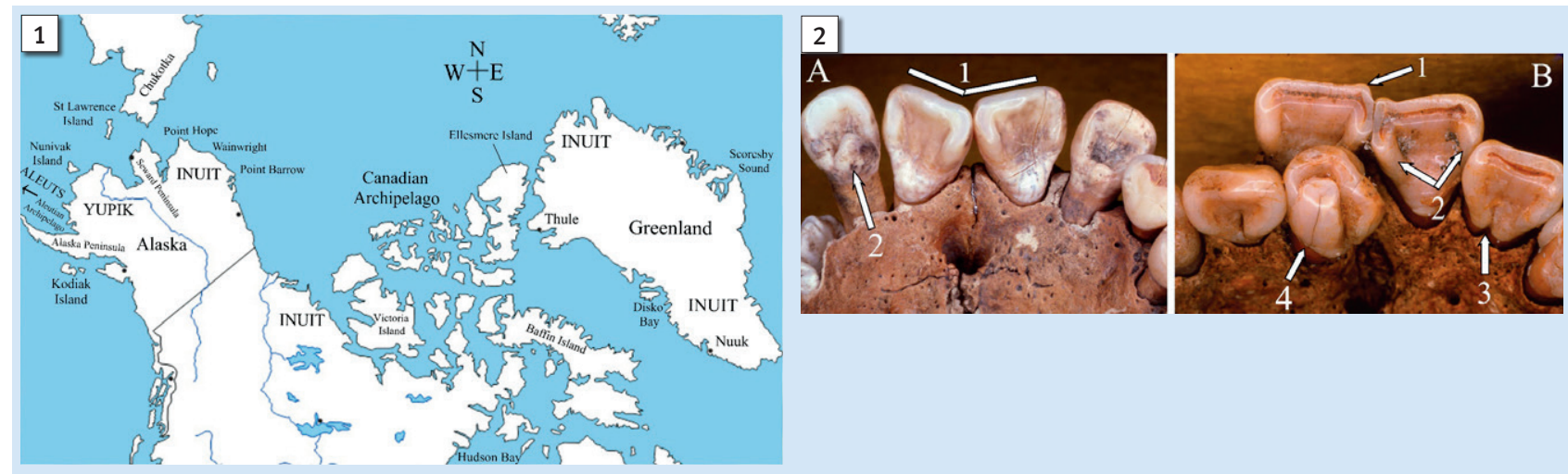

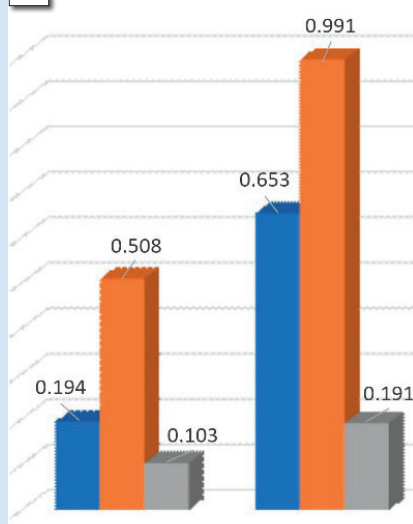

UI1 Winging

(1+)
UI1 Shoveling

$(2+)$

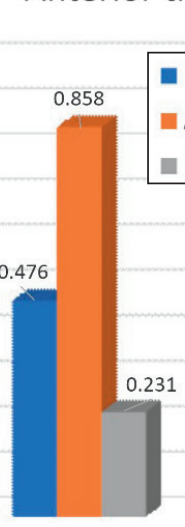

UI1 Double shoveling $(2+)$

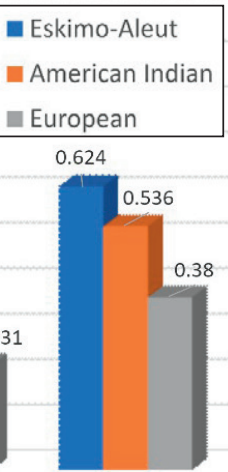

UI2

Interruption grooves (1+)

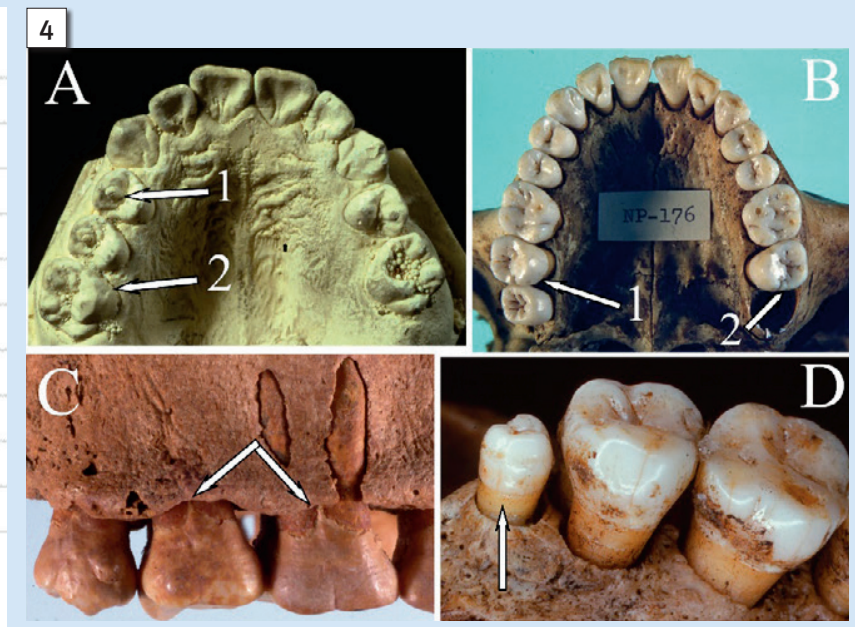

Figure 1 Distribution of Eskimos and Aleuts across the American Arctic (Aleutian Island archipelago too extensive to be illustrated).

Slika 1. Raspodjela Eskima i Aleuta po američkom Arktiku (Aleutski arhipelag prevelik je da bi bio ilustriran)

Figure 2 Anterior traits (A: 1. UI1 bilateral winging; 2. UI2 talon cusp; B: 1. UI1 double shoveling, 2. UI1 shoveling, 3. UI2 interruption groove, 4. supernumerary UI2 with talon cusp).

Slika 2. Obilježja prednjih zuba (A: 1. bilateralna meziopalatinalna rotacija (krilni V- postav) na UI1; 2. kandžasta kvržica na UI2; B: 1. labijalno lopatasti sjekutić UI1, 2. lopatasti sjekutić UI1, 3. interupcijska brazda UI2, 4. prekobrojni UI2 s kandžastom kvržicom)

Figure 3 Frequency variation of anterior traits.

Slika 3. Frekvencije obilježja na prednjim zubima

Figure 4 Maxillary traits (A: 1. UP1 odontome, 2. intermediate grade of UM1 Carabelli trait; B: 1. absence of hypocone on UM2, 2. cusp 5 on UM2; C: enamel extensions on UM1 and UM2; D: reduced UM3).

Slika 4. Obilježja gornjih zuba (A: 1. odontomi na UP1, 2. intermedijatni stupanj Carabellijeva svojstva na UM1; B: 1. odsutnost hipokonusa na UM2, 2. 5. kvržica na UM2; C: ekstenzije cakline na UM1 i UM2; D: reducirani UM3)

the upper second molar of modern humans, resulting in a 3-cusped tooth. Fig. 5 shows that about one-third of European UM2s are 3-cusped. For American Indians, this frequency is not half as high (12\%). Eskimo-Aleuts, despite their overall greater dental morphological complexity, almost match Europeans with 3-cusped UM2s around 30\%.

Of the remaining maxillary traits (Fig. 5), UM1 cusp 5 is basically equal among the three groups (ca. 15\%), which is on the low end of world variation for this trait (28). UM1 enamel extensions, by contrast, show a major difference between Native Americans who often exhibit this trait (40$45 \%)$ and Europeans who rarely do (3\%). For pegged-reduced-missing UM3, American Indians and Europeans have almost identical frequencies of around 16\%. Eskimo-Aleuts, with very large jaws and no paucity of space for third molars, exhibit the highest frequency at $22 \%$. kvržicama. Slika 5. pokazuje da otprilike jedna trećina UM2 kod Europljana ima tri kvržice. Za američke Indijance ta je učestalost upola manja (12\%). Eskimi Aleuti, unatoč općenito većoj morfološkoj složenosti, gotovo se podudaraju s Europljanima s trima kvržicama na UM2 u oko $30 \%$ slučajeva.

Od preostalih obilježja gornjih zuba (slika 5.), peta kvržica na UM1 u osnovi je jednako zastupljena među trima skupinama (oko $15 \%$ ), što pokazuje da to svojstvo nije toliko varijabilno (28). Suprotno tomu, caklinske ekstenzije na UM1 pokazuju veliku varijabilnost između američkih domorodaca koji često imaju to obilježje $(40-45 \%)$ i Europljana kod kojih je rijetko (3 \%). Američki Indijanci i Europljani imaju gotovo identične frekvencije reduciranog ili nedostajućeg UM3 od oko $16 \%$. Eskimi Aleuti s vrlo velikim čeljustima imaju najveću učestalost $-22 \%$. 


\section{5}

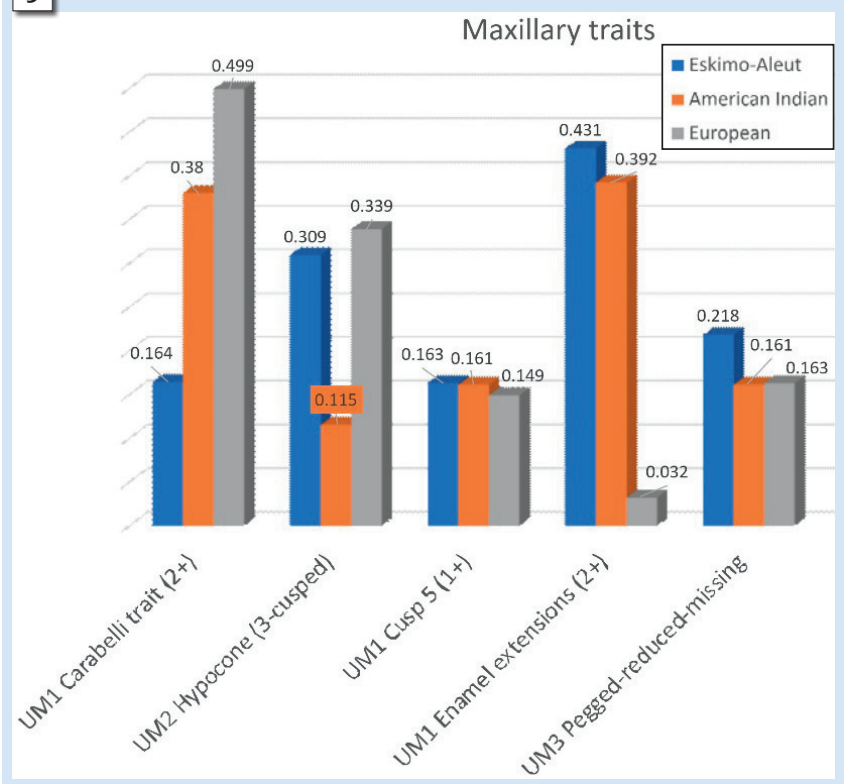

\section{6}
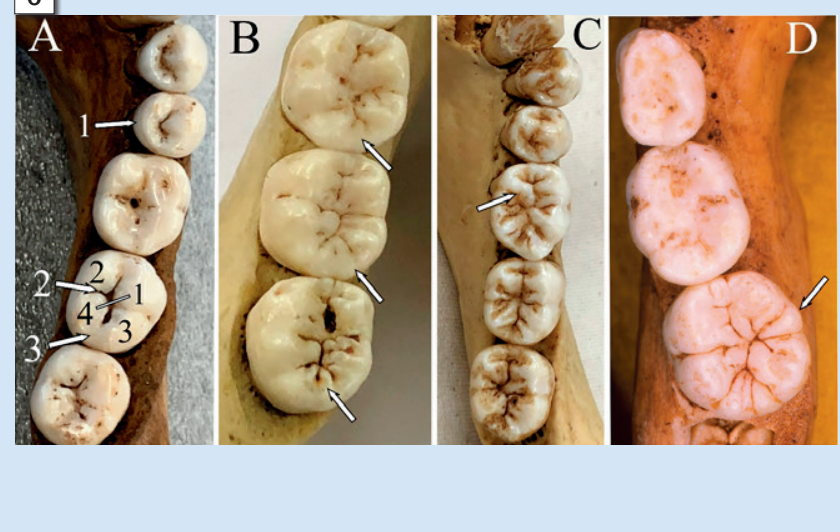

7

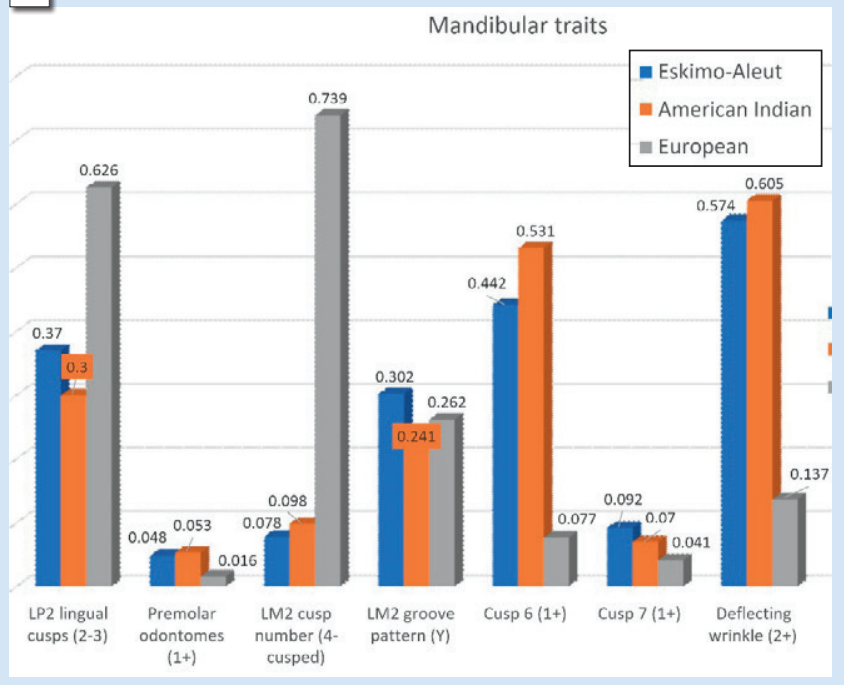

8
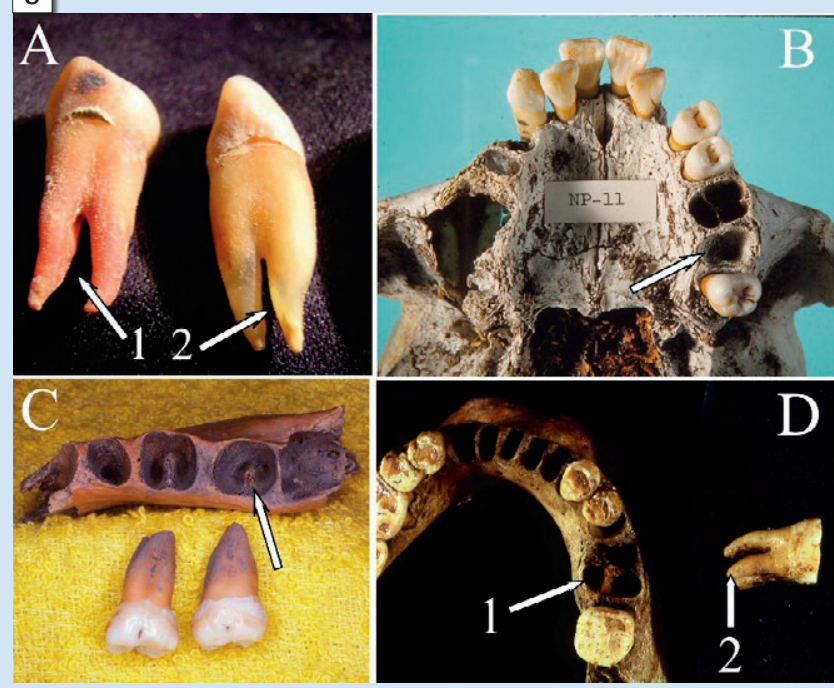

9

Root traits

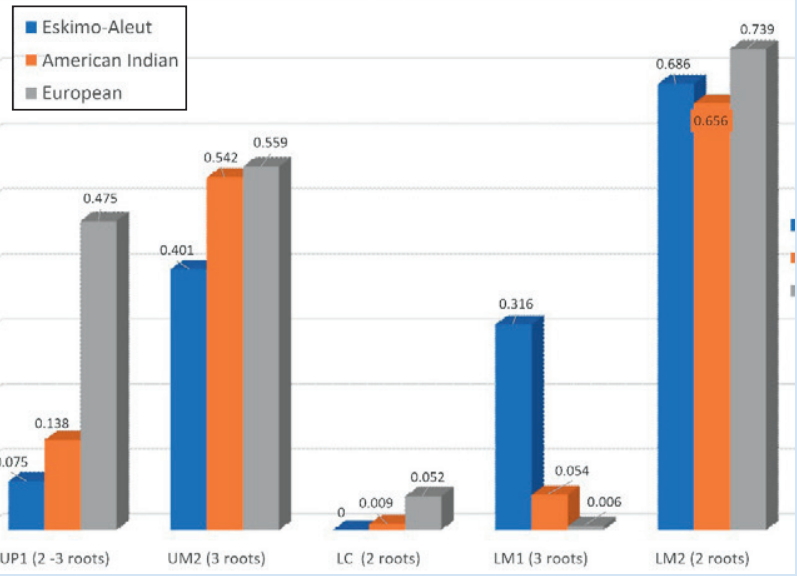

Figure 5 Frequency variation of maxillary traits.

Slika 5. Frekvencije obilježja gornjih zuba

Figure 6 Mandibular traits (A: 1. one lingual cusp on LP2, 2. LM2 $X$ pattern, 3. 4-cusped LM2 (lacking hypoconulid); B: arrows point at cusp 6 on all three lower molars; C: LM1 deflecting wrinkle; D: LM1 cusp 7).

Slika 6. Obilježja donjih zuba (A: 1. jedna lingvalna kvržica na LP2, 2. X obrazac na LM2, 3. četiri kvžice na LM2); B: strelice pokazuju 6. kvržicu na svim trima donjim kutnjacima; C: defleksijski nabor na LM1; D: 7. kvržica na LM1)

Figure 7 Frequency variation of mandibular traits.

Slika 7. Frekvencije obilježja donjih zuba

Figure 8 Root traits (A: 1. 2-rooted UP1, 2. 2-rooted LC; B: 1-rooted UM2; C: 1-rooted LM2; D: 3-rooted LM1).

Slika 8. Obilježja korijena (A: 1. dvokorijenski UP1, 2. dvokorijenski LC; B: jednokorijenski UM2; C: jednokorijenski LM2; D: trokorijenski LM1)

Figure 9 Frequency variation of root traits.

Slika 9. Frekvencije obilježja korijena 


\section{Mandibular crown traits}

Two premolar variants that are part of Turner's key trait list are multiple lingual cusps of LP2 and odontomes, or tuberculated premolars, of all upper and lower premolars. Key crown traits of the lower first molar include cusp 6, cusp 7, and the deflecting wrinkle. The nature of the contact between the major cusps at the central occlusal fossa (groove pattern) and the absence of the hypoconulid on LM2 that results in a 4-cusped lower second molar, are the two final key traits of the lower molars (Fig. 6).

Native Americans have the lowest frequencies of LP2 multiple lingual cusps (30-40\%) in the world (Fig. 7). All other populations have frequencies over 50\%, including Europeans at about $60 \%$. While extra lingual cusps are common, odontomes are rare. These conical occlusal tubercles are expressed in the sagittal sulcus between the buccal and lingual cusps of both upper and lower premolars. This trait is rare in European populations (1.6\%) but attains the world's highest frequency of about 5\% in Native Americans. The highest frequency ever reported was $17 \%$ in a St. Lawrence Island Eskimo sample (39). This trait is present in Asian and Pacific populations but is rarely expressed on African and European premolars (28).

Lower molar cusp number and groove pattern were two of the first polymorphic traits described for the human dentition. Fossil hominoids and early hominins exhibit five cusps on all three lower molars and contact between cusps 2 (metaconid; ML) and 3 (hypoconid; DB) at the central occlusal fossa, forming the so-called $Y$ pattern (40). These traits were described together as the Dryopithecus Y-5 pattern, which characterized the lower molars of the European Miocene ape of the same name (41). Most modern humans still exhibit the Y-5 pattern on LM1 but LM2 exhibits derived features in terms of changes in cusp number and contact. Regarding cusp number, the distal cusp (hypoconulid) is often lost on LM2, producing a 4-cusped tooth. For LM2, it is also more common to find cusp contact between cusps 1 (protoconid; $\mathrm{MB}$ ) and 4 (entoconid; DL), referred to as an X pattern.

LM2 cusp number is radically different between $\mathrm{Na}$ tive Americans and Europeans (Fig. 7). In line with loss of the hypocone on UM2, the hypoconulid is frequently absent on LM2 in Europeans (70-80\%). Even though EskimoAleuts parallel Europeans for hypocone loss and 3-cusped UM2, this is not evident for 4-cusped LM2. It is rare for either American Indians or Eskimo-Aleuts to show hypoconulid loss and 4-cusped LM2 (<10\%). In contrast to LM2 cusp number, the $\mathrm{Y}$ groove pattern on LM2 is expressed in similar frequencies between Europeans and Native American groups (25-30\%).

Beyond cusp number and groove pattern, the lower first molars exhibit three other polymorphic traits that vary widely on a world scale. Cusp 6, or tuberculum sextum, is a supernumerary cusp expressed between the entoconid and hypoconulid. Cusp 7, or tuberculum intermedium, is a wedge-shaped cusp that occurs between the metaconid and entoconid. The deflecting wrinkle is an occlusal polymorphism that involves the essential ridge of the metaconid. Typically, the essential ridge runs a straight course from the cusp tip to the central

\section{Obilježja donjih stražnjih zuba}

Dvije varijacije na pretkutnjacima koje su dio Turnerove glavne liste obilježja, višestruke su lingvalne kvržice na LP2 i odontomi, ili tuberkulirani gornji i donji pretkutnjaci. Ključna obilježja krune prvoga donjeg kutnjaka obuhvaćaju 6. i 7. kvržicu i deflekcijski nabor. Priroda kontakta između glavnih kvržica na središnjoj okluzalnoj fosi i odsutnost hipokonulida na LM2, što rezultira donjim drugim kutnjakom s četirima kvržicama, dva su završna ključna obilježja donjih kutnjaka (slika 6.).

Američki domorodci imaju najnižu frekvenciju LP2 s više lingvalnih kvržica $(30-40 \%)$ na svijetu (slika 7.). Sve ostale populacije imaju frekvencije veće od $50 \%$, uključujući Europljane s oko $60 \%$. Dok su dodatne lingvalne kvržice česte, odontomi su rijetki. Ti stožasti okluzalni tuberkuli pojavljuju se u sagitalnom sulkusu između bukalne i lingvalne kvržice gornjih i donjih pretkutnjaka. To je svojstvo rijetko u europskoj populaciji $(1,6 \%)$, ali dostiže najveću svjetsku učestalost od oko $5 \%$ kod američkih domorodaca. Najveća dosad prijavljena učestalost bila je $17 \%$ u uzorku Eskima s otoka St. Lawrencea (39). To obilježje pojavljuje se u azijskoj i pacifičkoj populaciji, ali rijetko se očituje na pretkutnjacima afričke i europske populacije (28).

Broj kvržica i uzorak jamica na donjim kutnjacima bila su prva dva polimorfna obilježja opisana za ljudske zube. Fosilni hominoidi i rani hominini imali su pet kvržica na svim trima donjim kutnjacima i kontakt između druge (metakonid; ML) i treće kvržice (hipokonid; DB) na centralnoj okluzalnoj fosi, tvoreći takozvani Y obrazac (40). Ta su obilježja zajedno opisana kao Y-5 uzorak driopiteka koji je karakterizirao donje kutnjake istoimenog majmuna iz europskoga miocena (41). Većina suvremenih ljudi još ima Y-5 obrazac na LM1, ali LM2 ima izvedene značajke u smislu promjene broja i kontakta kvržica. Kada je riječ o broju kvržica, distalna kvržica (hipokonulid) često se gubi na LM2, stvarajući zub s četirima kvržicama. Kad je riječ o LM2, također je češći kontakt između prve (protokonid; MB) i četvrte kvržice (entokonid; DL), što se naziva uzorkom $X$.

Broj kvržica na LM2 radikalno se razlikuje između američkih domorodaca i Europljana (slika 7.). U skladu s gubitkom hipokonusa na UM2, hipokonulida kod Europljana često nema (70 - 80 \%). Iako su Eskimi Aleuti slični Europljanima prema gubitku hipokonusa na UM2 s trima kvržicama, to se ne očituje na LM2 s četirima kvržicama. Rijetko kad Amerikanci ili Eskimi Aleuti imaju gubitak hipokonulida i LM2 s četirima kvržicama (< 10\%). Za razliku od broja kvržica na LM2, frekvencija Y-fisura na LM2 slična je između skupina Europljana i američkih domorodaca (25 - 30 \%).

Osim broja kvržica i fisurnog crteža, prvi donji kutnjaci imaju tri druga polimorfna svojstva koja se na svjetskoj razini znatno razlikuju. Šesta kvržica ili tuberculum sextum prekobrojna je kvržica između entokonida i hipokonulida. Sedma kvržica ili tuberculum intermedium klinasta je kvržica između metakonida i entokonida. Deflekcijski nabor je okluzalni polimorfizam koji uključuje greben metakonida. Greben obično vodi ravno od vrha kvržice do središnje okluzalne fose. U nekim se slučajevima greben savija ili odmiče na pola puta duž njegova toka stvarajući takozvani defleksijski nabor $(29,30)$. 
occlusal fossa. In some instances, the ridge bends or deflects about halfway along its course, producing the so-called deflecting wrinkle $(29,30)$.

For two LM1 variants, there is a dramatic difference between Europeans and Native Americans but little difference between the two Native American groups (Fig. 7). Cusp 6 is very common (45-55\%) in Native Americans and rare in Europeans $(<10 \%)$. The deflecting wrinkle shows the same pattern with very high frequencies in Native Americans (55$60 \%$ ) and a low frequency in Europeans (15\%). The final variable, cusp 7 , is rare in all three groups $(5-10 \%)$. The frequency of this variant falls below $10 \%$ in all world populations with but one exception - Sub-Saharan Africans. African populations have cusp 7 frequencies between 30 and $40 \%$.

\section{Root traits}

Some teeth are characterized by an almost invariant number of roots. For example, upper and lower incisors and upper canines have one root. Upper first molars exhibit three roots while lower first molars have two roots. Root number polymorphisms are evident in the lower canine, upper and lower premolars, and upper and lower second molars. Third molar root number is highly variable and environmentally labile, so they are not considered here. Briefly, lower canines sometimes exhibit an inter-radicular projection that produces two distinct roots, one buccal and one lingual. Upper premolars exhibit one, two, or three roots; for two roots, there is one buccal and one lingual root while for three rooted upper premolars, there are two buccal roots and a single lingual root. The derived condition for upper premolars is a single rooted tooth, a product of root fusion between the buccal and lingual roots. Although both upper premolars can exhibit all three root number variants, it is most common to have bifurcated roots on UP1, so this is considered the key tooth. For the upper second molar, the standard root configuration is two buccal roots and one lingual root. The variant in this instance involves root fusion producing a two rooted or single rooted UM2. Since this root fusion takes several forms, the frequency reported here is for the unfused 3-rooted UM2. The default root configuration in the lower molars is a single mesial and single distal root, forming a two rooted tooth. While LM1 almost invariably has two roots, LM2 can exhibit root fusion along the buccal margin forming a C-shaped form or both lingual and buccal margins can be fused. Again, the variant used to characterize populations is the standard 2-rooted LM2 with root fusion as the derived form. Root number for the lower canine, upper premolars, and upper and lower second molars is defined by the presence or absence of inter-radicular projections. The final root trait is different. Three-rooted lower first molars (3RM1) involve an accessory distolingual root (Fig. 8).

Of the five root traits, Eskimo-Aleuts exhibit distinctive frequencies for three (Fig. 9). They exhibit more root fusion than the other two groups for upper first premolars and upper second molars. They almost invariably have 1-rooted UP1 along with a significantly lower frequency of 3-rooted UM2. In concert with root fusion, they exhibit by far the highest frequency for the accessory root on LM1, the 3-root-
Za dvije LM1 varijante postoji drastična razlika između Europljana i američkih domorodaca, ali mala je razlika između dviju skupina američkih domorodaca (slika 7.). Šesta kvržica je vrlo česta $(45-55 \%)$ kod američkih domorodaca, a rijetka kod Europljana (<10\%). Defleksijski nabor slijedi isti obrazac $s$ vrlo visokim frekvencijama kod američkih domorodaca $(55-60 \%)$ i malom učestalošću kod Europljana (15 \%). Posljednja varijabla - sedma kvržica, rijetka je u svim trima skupinama $(5-10 \%)$. Učestalost te varijante pada ispod $10 \%$ u svim svjetskim populacijama, s jednom iznimkom supsaharskim Afrikancima. Afrička populacija ima frekvenciju između 30 i 40 \% za sedmu kvržicu.

\section{Obilježja korijena}

Neke zube obilježava broj korijena koji uglavnom nije varijabilan. Na primjer, gornji i donji sjekutići i gornji očnjaci imaju po jedan korijen. Prvi gornji kutnjaci imaju tri korijena, a donji prvi kutnjaci dva. Polimorfizam broja korijena vidljiv je na donjem očnjaku, gornjem i donjem pretkutnjaku te gornjim i donjim drugim kutnjacima. Treći korijen na kutnjaku vrlo je varijabilan i ekološki labilan, pa se ovdje ne uzima u obzir. Ukratko, donji očnjaci katkad imaju interradikularnu brazdu koja daje dva zasebna korijena - jedan bukalni i jedan lingvalni. Gornji pretkutnjaci imaju jedan, dva ili tri korijena; ako su dva korijena jedan je bukalni i jedan palatinalni, a u slučaju triju korijena gornjeg pretkutnjaka postoje dva bukalna i jedan palatinalni. Izvedeno stanje za gornje pretkutnjake je jednokorijenski zub, proizvod fuzije bukalnog i palatinalnog korijena. Iako oba gornja pretkutnjaka mogu imati sve tri inačice broja korijena, najčešći je dvokorijenski UP1. Za drugi gornji kutnjak standardna konfiguracija korijena je dva bukalna i jedan palatinalni. Varijanta u ovom slučaju uključuje fuziju korijena, stvarajući jednokorijenski ili dvokorijenski UM2. Budući da fuzija korijena ima nekoliko oblika, ovdje je navedena frekvencija za nefuzionirani UM2 s trima korijenima. Zadana konfiguracija korijena donjih kutnjaka jest jedan mezijalni i jedan distalni korijen, što ukupno čini dva korijena. Dok LM1 gotovo uvijek ima dva korijena, LM2 može imati fuziju korijena duž bukalnoga ruba tvoreći oblik u obliku slova $\mathrm{C}$, ili se mogu spojiti lingvalni i bukalni rub. Ipak, varijanta koja se primjenjuje za karakterizaciju populacije jest standardni dvokorijenski LM2 $s$ fuzijom korijena kao izvedenim oblikom. Broj korijena donjeg očnjaka, gornjeg pretkutnjaka i drugoga gornjeg i donjeg kutnjaka definiran je prisutnošću ili odsutnošću interradikularnih brazdi. Trokorijenski donji prvi kutnjaci (3RM1) uključuju prekobrojni distolingvalni korijen (slika 8.).

Od pet obilježja korijena, Eskimi Aleuti imaju različite frekvencije za tri (slika 9.). Kod njih je češća fuzija korijena negoli u ostalim dvjema skupinama za prve gornje pretkutnjake i druge gornje kutnjake. Gotovo uvijek imaju UP1 s jednim korijenom, uz značajno manju učestalost UM2 s trima korijenima. U kombinaciji s fuzijom korijena imaju najveću frekvenciju za prekobrojni korijen na LM1, trokorijenski donji prvi kutnjak (3RM1). Za donje očnjake iznimno je rijetka varijanta $s$ dvama korijenima u bilo kojoj skupini do- 
ed lower first molar (3RM1). For the lower canine, it is extremely rare to find a 2-rooted variant in either Native American group. This trait, while rare in general, is a hallmark of the European dentition where it attains a frequency of $5-10 \%$ $(28,42)$. The root fusion in Eskimo-Aleuts that sets them apart for UP1 and UM2 is not evident in LM2. All three groups have 2-rooted LM2s in a frequency around $65-75 \%$.

\section{Discussion}

In his extensive studies of Asian and Asian-derived populations, Turner $(43,44)$ observed consistent morphological differences between Northeast Asians (e.g., China, Japan, Mongolia, etc.) and Southeast Asians (e.g., Thailand, Philippines, Sumatra, etc.). While populations in the two regions exhibit the same suite of dental traits, some are consistently more common in Northeast Asians (e.g., UI1 shoveling and winging, 3-rooted LM1). With more complex and derived dentitions, Northeast Asians were placed in his Sinodont dental pattern. The more generalized and less complex dentition of Southeast Asians was described as the Sundadont pattern. Beyond Asia, he noted that Native Americans exhibit the Sinodont pattern, suggesting an ancestral-descendant relationship between Northeast Asians and New World populations. As the Pacific was settled primarily by Southeast Asians, Polynesians exhibit the Sundadont dental pattern. The dental pattern of Australo-Melanesians is reviewed in Scott et al. (28).

While New World populations were considered to exhibit the Sinodont pattern of Northeast Asians, a reanalysis of Asian, Pacific, and New World populations reveal that Native American populations express an extreme form of the Sinodont pattern, which Scott et al. (45) note as super-Sinodont. In a cluster analysis of Asian, Pacific, and New World populations, the New World samples grouped together (Eskimo-Aleuts and Indians from the Northwest Coast, North America, Mesoamerica, and South America), while Northeast Asians clustered with Southeast Asians. To develop this magnitude of difference among Sinodonts suggests the ancestors of Native Americans were isolated from Northeast Asians for an extended period (i.e., 8-10,00 years) prior to the settlement of the Americas. In this regard, dental morphological data are consistent with classic genetic markers (46) and mtDNA (47).

What evolutionary factors were involved in the divergence of New World populations from Northeast Asians? Scott et al. (28) demonstrated that the pattern of global differentiation derived from dental morphological traits was largely consistent with the assumptions of genetic drift and founder effect. There is, however, some indication that selection played a role in this divergence. When a gene in the ectodysplasin pathway, EDAR V370A, was shown to be partly involved in the development of shovel-shaped incisors (48) and lower molar cusp number (49), this opened up the possibility that selection might somehow influence dental trait frequencies. The effect may not be direct, as in the association of sickle-cell trait and malaria, but indirect where selection acted on other key biological variables that were tied more closely to fitness. Hlusko et al. (50, p. E4426) "hypothesize that selection on EDARV370A occurred in the Beringian refugium morodaca. To obilježje, iako je općenito rijetko, odlika je europske denticije gdje dostiže frekvenciju od 5 do $10 \%$ (28, 42). Fuzija korijena kod Eskima Aleuta koja ih izdvaja kad je riječ o UP1 i UM2, nije vidljiva na LM2. Sve tri skupine imaju dvokorijenske LM2 s frekvencijom oko 65 do $75 \%$.

\section{Rasprava}

U svojim opsežnim istraživanjima na Azijcima i populacijama azijskoga podrijetla, Turner $(43,44)$ je uočio konzistentne morfološke razlike između sjeveroistočnih (npr. iz Kine, Japana, Mongolije itd.) i jugoistočnih Azijaca (npr. iz Tajlanda, Filipina, Sumatre itd. ). Dok populacije u dvjema regijama imaju isti skup dentalnih obilježja, neka su dosljedno češća kod sjeveroistočnih Azijaca (npr. lopatasti sjekutići i krilni V-postav UI1, LM1 s 3 korijena). Sa složenijom i izvedenijom morfologijom zuba, sjeveroistočni Azijci smješteni su u njegov sinodontni dentalni uzorak. Općenitija i manje složena denticija jugoistočnih Azijaca opisana je kao sundadontni obrazac. Izvan Azije uočio je da Indijanci imaju sinodontni obrazac, sugerirajući odnos pretka i potomka između stanovništva azijskog sjeveroistoka i Novoga svijeta. Kako su Pacifik naseljavali uglavnom jugoistočni Azijci, Polinezijci imaju sundadontni dentalni obrazac. Dentalni obrazac australomelanezijanaca analizirali su Scott i suradnici (28).

Dok se smatralo da populacije Novoga svijeta imaju sinodontni obrazac sjeveroistočnih Azijaca, ponovna analiza stanovništva Azije, Tihog oceana i Novoga svijeta otkrila je da populacije američkih domorodaca imaju ekstremni oblik sinodontnog obrasca koji Scott i suradnici (45) opisuju kao supersinodont.

U klasterskoj analizi populacija Azije, Tihog oceana i Novoga svijeta, uzorci Novoga svijeta grupirani su zajedno (Eskimi Aleuti i Indijanci sa sjeverozapadne obale, Sjeverna Amerika, Srednja i Južna Amerika), a sjeveroistočni Azijci udruženi su s jugoistočnim Azijcima. Da bi nastala tolika razlika među sinodontima čini se da su predci američkih domorodaca dulje bili izolirani od sjeveroistočnih Azijaca (tj. od 8 do 10,00 godina) prije naseljavanja Amerike. $S$ tim u vezi su podatci o dentalnoj morfologiji u skladu s klasičnim genskim biljezima (46) i mtDNK-om (47).

Koji su evolucijski čimbenici bili uključeni u divergenciju populacije Novoga svijeta od sjeveroistočnih Azijaca? Scott i suradnici (28) pokazali su da je obrazac globalne diferencijacije izveden iz dentalnih morfoloških obilježja u velikoj mjeri u skladu s pretpostavkama genskoga pomicanja i efekta osnivača. No postoje pokazatelji da je selekcija bila itekako važna u tom razilaženju. Kad se pokazalo da je gen $E D A R$ V370A dijelom uključen u razvoj lopatastih sjekutića (48) i manjeg broja kvržica kutnjaka (49), to je otvorilo mogućnost da selekcija može nekako utjecati na frekvencije morfoloških obilježja. Učinak možda nije izravan, kao pri povezanosti srpastih stanica i malarije, nego neizravan u kojem je selekcija djelovala na druge ključne biološke varijable koje su bile više vezane za stanje. Hlusko i suradnici (50, str. E4426) postavili su hipotezu da se selekcija EDARV370A dogodila kod 
because it increases mammary ductal branching, and thereby may amplify the transfer of critical nutrients in vitamin D-deficient conditions to infants via mothers' milk. This hypothesized selective context for EDAR V370A was likely intertwined with selection on the fatty acid desaturase (FADS) gene cluster because it is known to modulate lipid profiles transmitted to milk from a vitamin D-rich diet high in omega-3 fatty acids." In such a scenario, shoveling would be a genetic hitchhiker where selection acted principally on associated pleiotropic variables.

For some morphological features of the Eskimo-Aleut dentition, natural selection seems counter-intuitive. For example, why would they have the world's highest frequency of odontomes? These occlusal tubercles are delicate structures that often fracture. If maintaining a complex dentition was a high priority, why do Eskimo-Aleuts have one of the world's highest frequencies of pegged-reduced-missing UM3? Eskimo jaws are huge so space was not an issue; in some instances, there would be room for a fourth molar. Hypocone loss on UM2 also runs counter to the need for a more morphologically complex dentition. Although Eskimo-Aleuts are often like American Indians (LM1 cusp 6, LM2 cusp number, LM2 root number), they show less complexity in the anterior teeth with lower frequencies of UI1 shoveling, double shoveling, and winging. The only instances where traits are more common in Eskimo-Aleuts include the greater root fusion seen in UP1 and UM2 and the addition of the accessory root on LM1, or 3RM1; in some Aleut samples, 3RM1 reached a frequency of over $50 \%$.

\section{Conclusions}

Dental morphological traits are powerful tools for assessing population origins and relationships when based on sample frequencies. These traits are also used in assessing the ancestry of single individuals (51). Despite showing some differences from American Indians, the Eskimo-Aleut suite of dental traits is closer to other Native Americans than to any other group. This similarity is due in part to the shared ancestry of the two groups who both arose from a late Pleistocene Beringian Standstill population that extended across much of Northeast Asia into Alaska. When the ancestors of American Indians finally broke free from the ice barriers responsible for the standstill, the progenitors of Eskimos and Aleuts remained in the far north. Because there was no absolute barrier to gene flow between the Old World and New World, this is the likely reason why some Eskimo-Aleut dental trait frequencies (e.g., UI1 winging, shoveling, double shoveling, and especially 3-rooted LM1) are closer to Northeast Asian populations than are American Indians. Genetic data show the same pattern (52). While natural selection may have played some role in the pattern of dental variation we observe in New World groups, chance processes through drift and founder effect were primary in establishing the pattern of dental variation we see in Asian and New World populations, including Eskimo-Aleuts with some evidence for gene flow among northern populations during the late Holocene (the past 12,000 years). stanovnika Beringije jer "povećava razgranavanje mamarnih mliječnih vodova $i$ na taj način može pojačati prijenos kritičnih hranjivih sastojaka u uvjetima nedostatka vitamina D kod dojenčadi preko majčina mlijeka. Taj pretpostavljeni selektivni kontekst za EDAR V370A vjerojatno se isprepletao sa selekcijom genskog skupa desaturaze masnih kiselina (FADS) jer se zna da mogu modulirati lipidni profil koji se prenosi u mlijeko iz prehrane bogate vitaminom D s visokim udjelom omega-3 masnih kiselina". U takvom scenariju lopatasti sjekutići bili bi genski autostoper pri čemu je selekcija djelovala uglavnom na pridružene pleiotropne varijable.

Za neke morfološke značajke denticije Eskima Aleuta prirodni odabir djeluje kontraintuitivno. Na primjer, zašto bi imali najvišu frekvenciju odontoma na svijetu? Ti okluzalni tuberkuli osjetljive su strukture koje se često lome. Ako je održavanje složene denticije glavni prioritet, zašto Eskimi Aleuti imaju jednu od najvećih frekvencija reduciranog ili nedostajućeg UM3 na svijetu? Čeljusti Eskima goleme su pa prostor nije bio problem - u nekim bi slučajevima bilo mjesta za četvrti kutnjak. Gubitak hipokonusa na UM2 također je u suprotnosti s potrebom za morfološki složenijom denticijom. Iako su Eskimi Aleuti često slični američkim Indijancima (6. kvržica na LM1, broj kvržica na LM2, broj korijena na LM2), oni pokazuju manju složenost na prednjim zubima s manjim frekvencijama krilnog V-postava ili lopatastih sjekutića UI1. Jedini slučajevi u kojima su obilježja češća kod Eskima Aleuta uključuju češću fuziju korijena na UP1 i UM2 i češću pojavu dodatnog korijena na LM1 ili 3RM1 - u nekim uzorcima Aleuta 3RM1 dostigao je frekvenciju veću od $50 \%$.

\section{Zaključak}

Dentalna morfološka obilježja moćan su alat za procjenu podrijetla i odnosa stanovništva na temelju učestalosti uzoraka. Ta se obilježja upotrebljavaju i u procjeni podrijetla pojedinaca (51). Unatoč tomu što pokazuju neke razlike u odnosu prema američkim Indijancima, Eskimi Aleuti imaju dentalna obilježja sličnija drugim američkim domorocima negoli bilo kojoj drugoj skupini. Ta sličnost dijelom je posljedica zajedničkog podrijetla dviju skupina koje potječu iz populacije kasne pleistocenske Beringije koja se proširila većim dijelom sjeveroistočne Azije do Aljaske. Kad su se predci američkih Indijanaca napokon oslobodili ledenih zapreka odgovornih za zastoj, potomci Eskima i Aleuta ostali su na krajnjem sjeveru. Budući da nije postojala apsolutna barijera za protok gena između Staroga i Novoga svijeta, to je vjerojatno razlog da su frekvencije nekih dentalnih obilježja Eskima Aleuta sličnije stanovništvu sjeveroistočne Azije negoli Amerikancima. Genetski podatci pokazuju isti obrazac (52). Iako je prirodna selekcija možda imala određenu ulogu u obrascu morfoloških varijacija zuba koje opažamo u skupinama Novoga svijeta, slučajni procesi kroz odljev i osnivački efekt bili su primarni u uspostavljanju morfoloških varijacija koje vidimo kod Azijaca i u populacijama Novoga svijeta, uključujući Eskime Aleute s dokazima o protoku gena među sjevernim populacijama tijekom kasnoga holocena (posljednjih 12 000 godina). 


\section{Acknowledgment}

I am indebted to my late mentor, colleague, and friend Christy G. Turner II for giving me a gentle push in the direction of dental anthropology when I entered graduate school in 1968. His energetic pursuit of dental morphological data for world populations resulted in a huge database that will be useful for scholars in the field well into the future. This paper owes a special debt to his earliest research on the dentition of Arctic peoples, which expanded substantially even after his dissertation on this topic was completed in 1967.

\section{Conflict of interest}

None declared

\section{Zahvala}

Dugujem zahvalu svom pokojnom mentoru, kolegi i prijatelju Christyju G. Turneru II. za njegov poticaj u smjeru dentalne antropologije kada sam 1968. upisao diplomski studij. Njegovo energično traženje dentalnih morfoloških podataka za svjetsku populaciju rezultiralo je ogromnom bazom podataka koja će biti korisna znanstvenicima na tom polju i u budućnosti. Ovaj rad ima poseban dug njegovim najranijim istraživanjima o zubima arktičkih naroda, koja su se znatno proširila čak i nakon što je njegova disertacija o toj temi dovršena 1967. godine.

\section{Sukob interesa}

Ne postoji.
Sažetak

Svrha rada: Rad daje pregled morfologije krune i korijena u populaciji Eskima Aleuta s američkog Arktika. U tom kontekstu uspoređuju se dentalne varijacije Eskima Aleuta s blisko povezanim američkim Indijancima i daljnje povezanim Europljanima. Materijali i metode: Karakterizacija varijacije učestalosti zubnih obilježja temelji se na opažanjima pokojnog Christyija G. Turnera II. i autora provedenima na približno 10000 denticija. Šesnaest obilježja krune i pet obilježja korijena analizirano je prema smjernicama Dentoantropološkog sustava Državnoga sveučilišta u Arizoni. Rezultati: Od 21 razmatranog dentalnog obilježja samo su tri pokazala neznatne razlike između Eskima Aleuta, američkih Indijanaca i Europljana (peta kvržica na UM1, fisurni crtež na LM2, broj korijena na LM2). Za preostala je zabilježena drastična razlika između dviju populacija Novoga svijeta i Europljana. lako općenito slični, Eskimi Aleuti i američki Indijanci razlikuju se u frekvencijama bilateralne meziopalatinalne rotacije (krilni Vpostav) na UI1, lopatastim i labijalno lopatastim sjekutićima, Carabellijevu svojstvu na UM1, tri kvržice na UM2, trokorijenskom UM2 i posebno trokorijenskom LM1. Zaključak: Razlike između triju skupina vjerojatno su rezultat genskoga odljeva i efekta osnivača, iako nedavno istraživanje alela EDAR V370A sugerira da neke dentalne varijable, poput lopatastog oblika i broja kvržica na donjim kutnjacima, mogu posredno odražavati prirodnu selekciju koja djeluje na druge varijable pod utjecajem toga alela.
Zaprimljen: 30. ožujka 2020

Prihvaćen: 25. svibnja 2020.

Adresa za dopisivanje

G. Richard Scott

University of Nevada Reno

Department of Anthropology

Reno NV 89557

+1775 750-3091

grscott@unr.edu

\section{Ključne riječi}

kruna zuba; korijen zuba; aljaški domorodci; sjeverno-američki indijanci; kontinentalni Europljani

\section{References}

1. Weyer EM. The Eskimos: their environment and folkways. New Haven: Yale University Press; 1932. p.491.

2. Birket-Smith K. Eskimos. New York: Crown Publishers; 1971. p.278.

3. Hoffecker JF, Elias SA, O'Rourke DH, Scott GR, Bigelow NH. Beringia and the global dispersal of modern humans. Evol Anth. 2016;25:64-78.

4. Hoffecker JF. A prehistory of the North: human settlement of the higher latitudes. New Brunswick: Rutgers University Press; 2015. p. 225.

5. Newman MT. The application of ecological rules to the racial anthropology of the aboriginal New World. Am Anthropol. 1983;55:311-327.

6. Roberts DF. Climate and human variability. Menlo Park CA: Cummings Publishing Company; 1978. p. 123.

7. Beals KL, Smith KL, Dodd SM. Brain size, cranial morphology, climate, and time machines. Curr Anth. 1984;25:301-330.

8. Waugh LM. Influence of diet on the jaws and face of the American Eskimo. J Am Dent Assoc. 1937;24:1640-1647.

9. Waugh LM. Dental observations among Eskimos. J Dent Res. 1937; 16:365-366.

10. Hylander WL. The adaptive significance of Eskimo craniofacial morphology. In: Dahlberg AA, Graber TM, editors. Orofacial growth and development. The Hague: Mouton; 1977. p. 129-169.

11. Halffman CM, Scott GR, Pedersen PO. Palatine torus in the Greenlandic Norse. Am J Phys Anthropol. 1992 Jun;88(2):145-61.

12. Scott GR, Schomberg R, Adams D, Swenson V, Pilloud MA. Northern exposure: mandibular torus in the Greenlandic Norse and the whole wide world. Am J Phys Anthropol. 2016 Nov;161(3):513521.

13. Turner CG, Cadien JD. Dental chipping in Aleuts, Eskimos and Indians. Am J Phys Anthropol. 1969 Nov;31(3):303-10.

14. Hrdlička A. Ritual ablation of front teeth in Siberia and America. Smithsonian Misc Coll. 1940;99:1-37.
15. Merbs CF. Anterior tooth loss in Arctic populations. Southwestern J Anthropol. 1968;24:20-32.

16. Brothwell D. Dental Anthropology. Oxford: Pergamon Press; 1963. p. 354.

17. Scott GR. A brief history of dental anthropology. In: Irish JD, Scott $\mathrm{GR}$, editors. A companion to dental anthropology. London: WileyBlackwell; 2016. p. 7-18.

18. Campbell TD. Dentition and palate of the Australian aboriginal. Adelaide: Hassell Press; 1983.

19. Middleton-Shaw JC. The teeth, the bony palate and the mandible in Bantu races of South Africa. London: Bale and Danielsson; 1931.

20. Pedersen PO. The East Greenland Eskimo dentition. Meddelelser om Grønland. 1949;1:1-252.

21. Moorrees CFA. The Aleut dentition. Cambridge MA: Harvard University Press; 1957. p. 196.

22. Dahlberg AA, Eskimo craniofacial studies. In: Jamison PL, Zegura SL, Milan FA, editors. Eskimos of Northwestern Alaska: a biological perspective. Stroudsburg PA: Dowden, Hutchinson \& Ross; 1978. p. 94-113.

23. Kraus BS. Carabelli's anomaly of the maxillary molar teeth: observations on Mexicans and Papago Indians and an interpretation of the inheritance. Am J Hum Genet. 1951;3:348-355.

24. Dahlberg AA. Materials for the establishment of standards for classification of tooth characters, attributes, and techniques in morphological studies of the dentition. Zollar Laboratory of Dental Anthropology, University of Chicago (mimeo); 1956.

25. Turner, C.G. The dentition of Arctic peoples. PhD dissertation, University of Wisconsin, Madison; 1967.

26. Turner, C.G. The dentition of Arctic peoples. New York: Garland Publishing, Inc; 1991.

27. Scott GR, Turner CG. The anthropology of modern human teeth: dental morphology and its variation in recent human populations. Cambridge: Cambridge University Press; 1997. p. 382. 
28. Scott GR, Turner CG, Townsend GC, Martinón-Torres M. The an thropology of modern human teeth: dental morphology and its variation in recent and fossil Homo sapiens. Cambridge: Cambridge University Press: 2018. p. 396.

29. Turner CG, Nichol CR, Scott GR. Scoring procedures for key morphological traits of the permanent dentition: the Arizona State University dental anthropology system. In: Kelley MA, Larsen CS, editors. Advances in Dental Anthropology. New York: Wiley-Liss; 1991. p. 13-31.

30. Scott GR, Irish JD. Human tooth crown and root morphology: the Arizona State University Dental Anthropology system. Cambridge: Cambridge University Press; 2017. p. 332.

31. Edgar HJH. Dental morphology: an illustrated manual. New York: Routledge; 2017. p. 202

32. Scott GR, Maier C, Heim K. Identifying and recording key morphological (nonmetric) crown and root traits. In: Irish JD, Scott GR, ed itors. A Companion to Dental Anthropology. London: Wiley-Blackwell; 2016. p. 247-264.

33. Scott GR, Dumancic I. Prepoznavanje i vrednovanje ključnih morfoloških obilježja krune I korijena zuba: Arizona State University dentoantropološki sustav (ASUDAS). In: Lauc T, editor. Den tal and Craniofacial Anthropology. Zagreb: University of Zagreb; 2019. p. 695-705.

34. Scott GR. Obituary: Christy Gentry Turner II (November 28, 1933 July 27, 2013). Am J Phys Anthropol. 2014;153:319-321.

35. Hrdlička A. Shovel-shaped teeth. Am J Phys Anthropol. 1920;3:429-465.

36. Scott GR, Anta A, de la Rua C, Schomberg R. Basque dental morphology and the "Eurodont" dental pattern. In: Scott GR, Irish JD, editors. Anthropological Perspectives on Tooth Morphology: Genetics, Evolution, Variation. Cambridge: Cambridge University Press; 2013. p. 296-318.

37. Scott GR. Population variation of Carabelli's trait. Hum Biol. 1980;52:63-78.

38. Hunter JP, Jernvall J. The hypocone as a key innovation in mammalian evolution. Proc Natl Acad Sci U S A. 1995 Nov 7;92(23):10718 22.

39. Scott GR, Gillispie TE. The dentition of prehistoric St. Lawrence Island Eskimos: variation, health and behavior. Anthropol Pap Univ Alaska. 2002;2:50-72.

40. Gregory WK. The Origin and Evolution of the Human Dentition. Baltimore: Williams and Wilkins; 1922.
41. Gregory WK, Hellman M. The dentition of Dryopithecus and the origin of man. Am Mus Nat Hist Anthropol Pap. 1926;28:1-117.

42. Lee C, Scott GR. Two-rooted lower canines: a European trait and sensitive indicator of admixture across Eurasia. Am J Phys Anthropol. 2011 Nov;146(3):481-5.

43. Turner CG. Late Pleistocene and Holocene population history of East Asia based on dental variation. Am J Phys Anthropol. 1995 Jun;97(2):101-11.

44. Turner CG. Major features of Sundadonty and Sinodonty, including suggestions about East Asian microevolution, population history, and late Pleistocene relationships with Australian aboriginals. Am J Phys Anthropol. 1990 Jul;82(3):295-317.

45. Scott GR, Schmitz K, Heim K, Paul KA, Schomberg R, Pilloud MA. Sinodonty, Sundadonty, and the Beringian standstill model: issues of timing and migrations into the New World. Quat Int. 2018;466B:233-246.

46. Nei M, Roychoudhury AK. Evolutionary relationships of human populations on a global scale. Mol Biol Evol. 1993 Sep;10(5):92743.

47. Tamm E, Kivisild T, Reidla M, Metspalu M, Smith DG, Mulligan C), et al. Beringian standstill and spread of Native American founders. PLoS One. 2007 Sep 5;2(9):e829.

48. Kimura R, Yamaguchi T, Takeda MT, Kondo O, Toma T, Haneji K. et al. A common variation in EDAR is a genetic determinant of shovel-shaped incisors. Am J Hum Genet. 2009 Oct;85(4):528-35.

49. Park JH, Yamaguchi T, Watanabe C, Kawaguchi A, Haneji K, Takeda $M$, et al. Effects of an Asian-specific nonsynonymous EDAR variant on multiple dental traits. J Hum Genet. 2012 Aug;57(8):50814.

50. Hlusko LJ, Carlson J, Chaplin G, Elias SA, Hoffecker JF, Huffman M, Jablonski NJ, Monson TA, O'Rourke DH, Pilloud MA, Scott GR. Evidence of environmental selection on the mother-to-infant transmission of vitamin $D$ and fatty acids during the last ice age in Beringia. Proc Natl Acad Sci U S A. 2018 May 8;115(19):E4426E4432.

51. Scott GR, Navega D, Coelho J, Pilloud MA, Cunha E, Irish JD. rASUDAS: a new web-based application for estimating ancestry from tooth morphology. Forensic Anthropol. 2018;1:18-31.

52. Reich D, Patterson N, Campbell D, Tandon A, Mazieres S, Ray N, et al. Reconstructing native American population history. Nature. 2012 Aug 16;488(7411):370-4. 